\title{
Shattercane X ALS-Tolerant Sorghum F1 Hybrid and Shattercane Interference in ALS-Tolerant Sorghum
}

\author{
Rodrigo Werle ${ }^{1}$, Jared J. Schmidt ${ }^{1}$, John Laborde ${ }^{1}$, Angela Tran ${ }^{1}$, Cody F. Creech ${ }^{1} \&$ John L. Lindquist ${ }^{1}$ \\ ${ }^{1}$ Department of Agronomy and Horticulture, University of Nebraska-Lincoln, USA \\ Correspondence: John L. Lindquist, Department of Agronomy and Horticulture, University of Nebraska-Lincoln, \\ Lincoln NE 68583-0915, USA. Tel: 1-402-472-2771. E-mail: jlindquist1@unl.edu
}

Received: December 23, 2013 Accepted: January 28, 2014 Online Published: March 15, 2014

doi:10.5539/jas.v6n4p159 URL: http://dx.doi.org/10.5539/jas.v6n4p159

\begin{abstract}
ALS-tolerant grain sorghum cultivars are expected to be available for farmers within the next few years. Knowing that: $i$ ) crosses between sorghum and shattercane are likely to occur resulting in crop-to-weed gene flow; $i$ ) ALS-susceptible shattercane X ALS-tolerant grain sorghum F1 hybrids (hybrids) were ultimately resistant to ALS-herbicides under field conditions; and iii) hybrid fitness is equal to, or greater than, the wild parent, we conducted a greenhouse study to compare the competitive effect of shattercane and hybrid on sorghum, and whether or not herbicide application would influence the competitive ability of the hybrid plants. An additive design was used where weed densities varied while that of crop remained constant. The treatment design was a factorial with two weedy genotypes, shattercane and hybrid, with the hybrid being either exposed or not exposed to an ALS-herbicide application (nicosulfuron $\left(26.25 \mathrm{~g}_{\text {ai }} \mathrm{ha}^{-1}\right)+$ rimsulfuron $\left(13.16 \mathrm{~g}\right.$ ai ha $\left.{ }^{-1}\right)$ ), and five weed densities $\left(0,1,2,3\right.$, and 4 plants pot $\left.{ }^{-1}\right)$. Sorghum density was kept at 1 plant pot ${ }^{-1}$. F-tests were performed to compare differences across treatment levels. Shattercane and hybrid produced similar amounts of total above ground biomass within each density, and herbicide exposure did not decrease hybrid biomass production. Moreover, shattercane and hybrid competed similarly with sorghum, and a herbicide application did not reduce the competitive ability of the hybrid. Sorghum wild relatives must be managed by alternative methods before and during the adoption of ALS-tolerant sorghum technology to avoid gene flow and crop yield loss due to competition.
\end{abstract}

Keywords: crop-weed competition, weedy relative, additive design, F-test

\section{Introduction}

Weeds are a major problem in agriculture because they compete with crops for resources (water, nutrients, light) and reduce yield quantity and quality (Zimdahl, 2007). Many studies have been conducted to describe the relationship between crop yield and competitor density (Lindquist et al., 1996; Lindquist et al., 1999; Williams $\&$ Boydston, 2006). Empirical models that describe this relationship are valuable tools for assessing the relative competitiveness of crop and weed species. For example, Moolani, Knake, and Slife (1964) demonstrated that smooth pigweed (Amaranthus hybridus L.) was far more competitive against soybeans (Glycine max L.) than corn (Zea mays L.), and Cousens (1996) reported barley (Hordeum vulgare L.) being more competitive against annual ryegrass (Lolium rigidum Gaud.) than wheat (Triticum aestivum L.). Additive designs, where crop density is held constant while weed density varies (Swanton, Nkoa, \& Blackshaw, 2013), have been widely used in field and greenhouse studies looking at yield loss-weed density relationships because they accurately reflect the reality that weeds occur within a crop planted at constant density.

Grain sorghum (Sorghum bicolor (L.) Moench ssp. bicolor) is considered the fifth most important cereal crop in the world after wheat, rice (Oryza sativa L.), corn, and barley, and is the third-most common cereal planted in the United States, trailing corn and wheat (Defelice, 2006). Grain sorghum is a warm season $\mathrm{C}_{4}$ grass species that is highly efficient in the conversion of solar energy and use of water. Sorghums are cultivated throughout the world for food, fodder, syrup, and biofuel production. In the USA, the crop is primarily used for livestock feed and is ranked second after corn for ethanol production (Paterson, 2008). In spite of the agronomic potential and food value of grain sorghum, the number of acres of sorghum production has declined in recent years in many parts of the United States (Lust, Barnaby, O'Brien, \& Waller, 2000), in part because the number of options for weed management in sorghum is limited. 
Most postemergence (POST) herbicides labeled for use in sorghum have only limited activity on annual grasses and are mainly used to control broadleaf species. Consequently, preemergence (PRE) herbicides are the primary option for annual grass control in grain sorghum (Hennigh, Al-Khatib, \& Tuinstra, 2010). However, grain sorghum is often grown in dry environments, and the absence of precipitation often reduces the activation and efficacy of PRE herbicide treatments (Hennigh et al., 2010).

Acetolactate synthase (ALS) inhibitor herbicides are widely used to control grass weeds in broadleaf and some grass crops (Hennigh et al., 2010). However, conventional sorghum is susceptible to these herbicides. In 2004, a wild sorghum genotype exhibiting resistance to ALS herbicides was identified in Kansas. A project was then initiated at Kansas State University to develop and ultimately commercialize grain sorghum varieties with tolerance to ALS-inhibiting herbicides (Tuinstra \& Al-Khatib, 2008). The development of this technology has the potential to improve weed control options in grain sorghum production by allowing for POST control of grass weeds. This might increase the use of grain sorghum in crop rotations and an expansion of sorghum acreage in environments where sorghum is better adapted than corn, but where corn is typically cultivated because of the availability of more herbicide options. DuPont has acquired the license to the herbicide tolerance gene from Kansas State University and has branded the technology as "Inzen Z". The ALS-tolerant grain sorghum varieties are expected to be on market in 2015 (Saunders D. W., personal communication).

Shattercane (Sorghum bicolor (L.) Moench ssp. drummondii (Nees ex Steud.) de Wet ex Davidse) is a serious weed in agronomic crops worldwide, especially in grain sorghum production (Hans \& Johnson, 2002; Kegode \& Pearce, 1998). Shattercane is a de-domesticated sorghum with many similarities to grain sorghum. Shattercane and grain sorghum are both diploid $(2 \mathrm{n}=20)$, pollinated by wind, and sexually compatible, which can result in hybridization (Defelice, 2006; Sahoo, Schmidt, Pedersen, Lee, \& Lindquist, 2010; Schmidt, Pederson, Bernards, \& Lindquist, 2013). Schmidt et al. (2013) observed shattercane X grain sorghum hybridization rates as high as $26 \%$ for an individual shattercane planted within a grain sorghum field. They also observed hybridization via pollen transfer by wind as far as $200 \mathrm{~m}$ from the edge of the sorghum field. The introgression of a trait from grain sorghum into shattercane populations will depend on synchrony of flowering, frequency of hybridization, relative fitness of the hybrid, and relative fitness conferred by that trait in subsequent populations (Schmidt et al., 2013). Sahoo et al. (2010) found that the fitness of shattercane $X$ grain sorghum F1 hybrids was similar or greater than the shattercane parent with respect to several metrics (i.e., plant height, seed production, and biomass), indicating that F1 hybrids may be as competitive as shattercane, if not more. There is apparently no barrier to prevent the transfer of any beneficial or neutral traits from the crop to weedy relatives (Sahoo et al., 2010; Schmidt et al., 2013). Werle, Bernards, Sattler, and Lindquist (2013) reported that the cross between ALS-susceptible shattercane X ALS-tolerant sorghum produced F1 hybrids that were resistant $(0 \%$ mortality) even at a high application rate (4 times the recommended rate of nicosulfuron + rimsulfuron). Hybrid plants showed some injury at 7 days after herbicide treatment (DAT), but completely recovered from that injury by 28 DAT. The shattercane parent was highly susceptible and plants were dead by 28 DAT.

Knowing that: $i$ ) crosses between grain sorghum and shattercane are likely to occur under field conditions resulting in gene flow from crop to weed (Schmidt et al., 2013); ii) shattercane x ALS-tolerant sorghum F1 hybrids were resistant to ALS herbicides (Werle et al., 2013), though slightly injured shortly after treatment; and iii) F1 hybrid fitness is equal to, or greater than, the wild parent (Sahoo et al., 2010), we hypothesized that untreated shattercane and F1 hybrids would compete similarly with grain sorghum and that herbicide exposure would reduce the competitiveness of the hybrid relative to the untreated shattercane or hybrid. Therefore, the objective of this study was to compare the competitive ability of shattercane and the shattercane X ALS-tolerant grain sorghum F1 hybrid against grain sorghum with and without herbicide treatment using an additive design experiment in a controlled environment.

\section{Materials and Methods}

\subsection{Greenhouse Experiment and Data Collection}

A greenhouse study was conducted at the University of Nebraska-Lincoln to quantify the relative competitiveness of ALS-susceptible shattercane and the shattercane X ALS-tolerant grain sorghum F1 hybrid (hereafter referred to as "hybrid") against the ALS-tolerant grain sorghum ("6002 inbred parent line"; hereafter referred to as "sorghum") with and without ALS herbicide application. An additive design (Swanton et al., 2013) was utilized for this experiment, where hybrid or shattercane densities varied while that of sorghum remained constant. The treatment design was a factorial with two weedy genotypes, shattercane and hybrid, with the hybrid being either exposed or not exposed to a herbicide application (total of three treatment levels), and five 
weed densities $\left(0,1,2,3\right.$, and 4 plants pot $\left.^{-1}\right)$, in a randomized complete block with four replications. The study was replicated twice in time.

Pots ( $16 \mathrm{~cm}$ in diameter, $16 \mathrm{~cm}$ in height) were filled with $2.1 \mathrm{~L}$ of an $8: 1: 1$ mixture of soil:sand:vermiculite. The soil used was a Sharpsburg silty clay loam containing $92 \mathrm{ppm} \mathrm{N}, 39 \mathrm{ppm} \mathrm{P}$, and 249 ppm K, with a pH of 6.3 and $2.5 \%$ organic matter. Seeds for all genotypes were planted at $3 \mathrm{~cm}$ depth. Sorghum seeds were planted in the center of each pot (five and eight seeds during first and second experimental run, respectively, to ensure sufficient emergence since the sorghum seed used in this study had low germination; data not shown). The shattercane and hybrid were planted around the perimeter of the pot at twice the desired rate. The first experimental run started on October 182012 and the second on October 25 2012. Greenhouse temperatures were set at $24 / 19 \mathrm{C}$ day/night cycles. Supplemental lighting, in addition to natural radiation, was provided to achieve a $14 \mathrm{hr}$ day with the use of metal halide lamps. Pots were watered on a daily basis.

Ten days after planting (DAP), plants were thinned to the final desired densities of one sorghum plant in the center, and $0,1,2,3$, or 4 hybrid or shattercane plants uniformly distributed around the sorghum plant. After the plants were thinned, experimental units (pots) were randomly arranged in blocks and spaced evenly on a table. All treatments were fertilized at 14 DAP with 100 milliliters of a fertilizer solution consisting of 30 grams of Peters General Purpose 20-20-20 water soluble fertilizer (Scotts, Marysville, OH) diluted in 3.785 L of water.

The hybrid plants selected for the herbicide treatment were sprayed with a mixture of nicosulfuron $(26.25 \mathrm{~g}$ ai $\mathrm{ha}^{-1}$ ) and rimsulfuron $\left(13.16 \mathrm{~g}_{\mathrm{ai} \mathrm{ha}}{ }^{-1}\right)$, which was expected to be the recommended mixture for the ALS-tolerant sorghum or "Inzen Z" technology (Saunders D. W., personal communication). A 1\% Prime Oil crop oil concentrate (Agriliance, Inver Grove Heights, MN) was also added to the spray solution. Herbicide applications were made using a $140 \mathrm{~L} \mathrm{ha}^{-1}$ carrier volume and TP8001E flat-fan nozzle tip (TeeJet Technologies, Spraying Systems Co., Wheaton, IL) at a pressure of $241 \mathrm{kPa}$ within a spray chamber (Research Track Sprayer; DeVries, Hollandale, MN). Herbicide applications were made 21 DAP when hybrid plants were 15 to $20 \mathrm{~cm}$ tall. Each run of the experiment was harvested 56 DAP by clipping plants at the soil surface. The sorghum plant was bagged separately from the weedy plants for each experimental unit. All harvested plant material was dried to constant weight at $60 \mathrm{C}$ and sample dry weights recorded.

\subsection{Statistical Analysis}

An ANOVA was performed to compare weed-free sorghum biomass yield $\left(\mathrm{g} \mathrm{pot}^{-1}\right)$ across treatment levels and experimental runs using the aov function of $\mathrm{R}$ version 2.15.1 (R Foundation for Statistical Computing, Wien, Austria). Sorghum biomass yield loss $\left(\mathrm{Y}_{\mathrm{L}}\right)$ for each treatment at each density was then calculated as a percentage biomass yield reduction caused by the presence of weeds related to the average weed-free biomass yield $\left(\mathrm{g} \mathrm{pot}^{-1}\right)$ Analyses were performed by regressing sorghum $\mathrm{Y}_{\mathrm{L}}(\%)$ and aboveground weed biomass $\left(\mathrm{W}_{\mathrm{BIO}}, \mathrm{g} \mathrm{pot}^{-1}\right)$ against density of hybrid (sprayed and nonsprayed with herbicide) and shattercane. The rectangular hyperbola proposed by Cousens (1985) was fit to the data and compared among treatments:

$$
\mathrm{Y}_{\mathrm{L}} \text { or } \mathrm{W}_{\mathrm{BIO}}=\frac{I D}{1+\left(\frac{I}{A}\right) D}
$$

where $D$ represents the density of the weedy species $\left(\right.$ plants $\operatorname{pot}^{-1}$ ), $I$ represents $\mathrm{Y}_{\mathrm{L}}$ or $\mathrm{W}_{\mathrm{BIO}}$ per unit weed density as $D$ approaches 0 , and $A$ represents $\mathrm{Y}_{\mathrm{L}}$ or $\mathrm{W}_{\mathrm{BIO}}$ as $D$ approaches $\infty$ (or maximum expected yield loss or weed biomass). The parameters for this equation are easily interpreted and meaningful in agronomic terms (Lindquist et al., 1996; Lindquist et al., 1999; Williams \& Boydston, 2006).

In order to evaluate treatment effect on competitiveness against sorghum and biomass production, the "variance ratio", "extra-sum-of-squares F-test", or "F-test", as described by Lindquist et al. (1996), Motulsky and Christopoulos (2004), and Ritz and Streibig (2008), respectively, was performed. This statistical test evaluates the difference between residual sum of squares (RSS) for two considered models. In order to use this approach, two models need to be fitted to the data: a full model (FULL) and a submodel (SUB) of the full model (this approach is recommended for nested models). For our full model, we estimated parameters for all three treatments separately (total of 6 parameters), whereas for the submodel we estimated the parameters for a single model fit to the data of all treatments combined (total of 2 parameters). Models were fitted to the data and parameters estimated using the $n l s$ function (Ritz \& Streibig, 2008) of R version 2.15.1 (R Foundation). The following equation represents the F-test performed according to this approach:

$$
\mathrm{F}=\frac{\left(R S S_{S U B}-R S S_{F U L L}\right) /\left(d f_{S U B}-d f_{F U L L}\right)}{R S S_{F U L L} / d f_{F U L L}}
$$


where: $\operatorname{RSS}_{S U B}$ and $\mathrm{RSS}_{F U L L}$ represent the minimized residual sums of squares for the parameter estimates of the submodel and full model, respectively; $\mathrm{df}_{S U B}$ and $\mathrm{df}_{F U L L}$ represent the degrees of freedom for the submodel and full model, respectively. A large F-value indicates that the two nested models are different, whereas a small F-value indicates that both models provide similar fit to the data. The $\mathrm{F}$-value is then quantified as a $p$-value obtained from the F-distribution $\left(\mathrm{df}_{S U B}-\mathrm{df}_{F U L L}, \mathrm{df}_{F U L L}\right)$. P-value $<0.05$ indicates that models are significantly different; therefore, the full model (with parameters for each treatment level) should be used (indicating that treatments are behaving differently), whereas P-value $>0.05$ indicates that nested models are not different and the simplest model (the submodel in this case) may be used (indicating no differences among treatments). The F-test was computed for each model using the $n l s$ function ANOVA command (Ritz \& Streibig, 2008) of R version 2.15.1 (R Foundation).

\subsection{Model Goodness of Fit}

Root mean square error (RMSE) and modeling efficiency (ME) were calculated and used to test goodness of fit and used as indicators of model quality. The RMSE was calculated according to Roman, Murphy, and Swanton (2000):

$$
\operatorname{RMSE}=\left[\frac{1}{n} \sum_{i=1}^{n}(P i-O i)^{2}\right]^{1 / 2}
$$

where $\mathrm{P} i$ is the predicted and $\mathrm{O} i$ the observed value, and $n$ is the total number of comparisons. The smaller the RMSE value, the closer the observed values are to predicted values. The ME differs from $\mathrm{R}^{2}$ only by not having a lower bound, was calculated according to Mayer and Butler (1993):

$$
\mathrm{ME}=1-\left[\frac{\sum_{i=1}^{n}(O i-P i)^{2}}{\sum_{i=1}^{n}(O i-\overline{0} i)^{2}}\right]
$$

where $\bar{O} i$ is the mean observed value. ME values can range from $-\infty$ and 1 , with values closer to 1 indicating more accurate predictions.

\section{Results and Discussion}

\subsection{Crop-Weed Competition}

Weed-free sorghum biomass yield at 56 DAP was not influenced by the interaction $(\mathrm{P}=0.21)$ or main effect of treatment level and experimental run $(\mathrm{P}=0.85$ and 0.39 , respectively). Therefore, the average weed-free sorghum biomass yield across treatment levels and experimental runs, $6.44 \pm 0.52 \mathrm{~g} \mathrm{pot}^{-1}$ (mean \pm standard error, $\mathrm{n}=24$ ), was used to calculate sorghum biomass yield loss $\left(\mathrm{Y}_{\mathrm{L}}\right)$.

According to the F-test, full model and submodel were not different (at critical $\mathrm{P}=0.05$ ) for both sorghum biomass yield loss $\left(\mathrm{Y}_{\mathrm{L}}, \%\right)(\mathrm{P}=0.48)$ and weed biomass $\left(\mathrm{W}_{\mathrm{BIO}}, \mathrm{g} \mathrm{pot}^{-1}\right)(\mathrm{P}=0.06)$ regressed against weed density. As no difference in parameters across treatment levels was detected, a single model for each nonlinear regression function was fitted to the $\mathrm{Y}_{\mathrm{L}}$ (Figure 1) and $\mathrm{W}_{\mathrm{BIO}}$ (Figure 2) data. Therefore, shattercane and the hybrid competed similarly with sorghum, and herbicide application did not reduce the competitive ability of the hybrid (Figure 1), even though interveinal chlorosis was observed in the hybrid at 7 days after treatment (DAT). Since the herbicide treated hybrid plants recovered from the treatment and competed with sorghum similarly to the nonsprayed hybrid or shattercane plants, our initial hypothesis was rejected.

Sorghum biomass yield loss observed at four shattercane or hybrid plants per pot ranged from 75 to $95 \%$. According to the parameters estimated for the rectangular hyperbola (Figure 1), $95 \%$ sorghum biomass yield loss can be expected at low weed densities ( $I$ coefficient), and a maximum yield loss of $100 \%$ at high weed densities ( $A$ coefficient). In a field study, Vesecky, Feltner, and Vanderlip (1973) planted grain sorghum at 76 $\mathrm{cm}$ row spacing and transplanted shattercane seedlings in the center of the interrow between two sorghum rows at $90,45,30$, and $15 \mathrm{~cm}$ apart (low to high density). At these densities, shattercane interference reduced sorghum biomass yield on average in $52 \%, 64 \%, 79 \%$, and $85 \%$, respectively, and reduced sorghum grain yield by $69 \%$, $81 \%, 93 \%$, and $97 \%$, respectively. These results suggest that shattercane interference affected sorghum grain yield more than biomass production. The ALS-tolerant grain sorghum genotype used in our study was an inbred line, and is therefore unlikely to be as competitive as an ALS-tolerant grain sorghum cultivar. Even in the absence of competition, high variability for sorghum biomass yield was observed (Figure 1). Guneyli, Burnside, and Nordquist (1969) reported sorghum cultivars to be more competitive than parental sorghum inbred lines for all metrics evaluated in their study (e.g., germination and emergence rate, seedling vigor, rate of root and shoot development). However, our goal was to compare the relative effect of shattercane and the hybrid on the crop and results show that their competitive ability did not vary. Therefore, we expect that the yield loss incurred by a 
grain sorghum cultivar may be less than that observed here, but that the relative effect of shattercane or the hybrid interference would be equivalent.

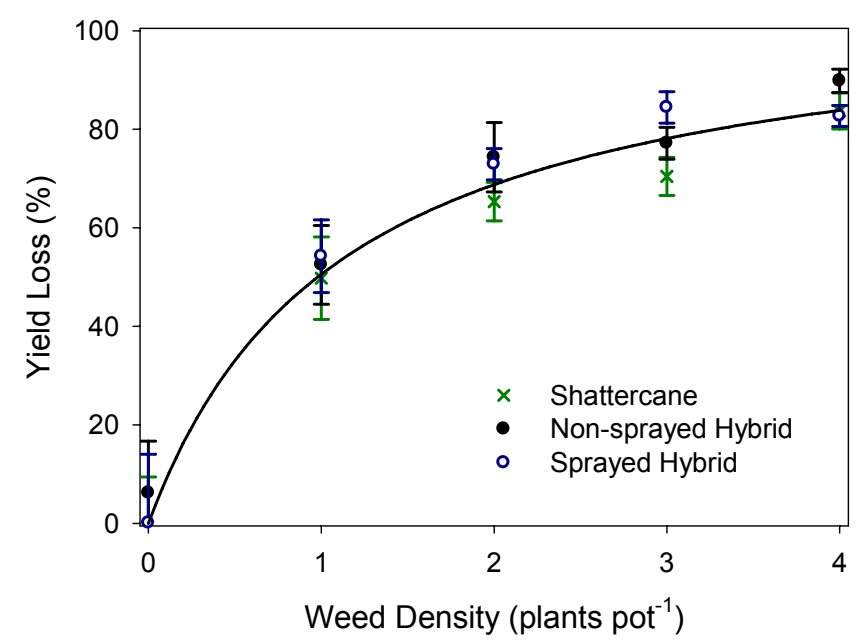

Figure 1. Relationship between percent sorghum biomass yield loss $\left(\mathrm{Y}_{\mathrm{L}}\right)$ and weed density (plants pot $\left.{ }^{-1}\right)$ at 56 days after planting. Solid line represents the best fit of equation (1) to the data and symbols represent the mean ( \pm standard error) for each genotype. Model coefficient estimates: $I=95.5 \pm 21.8$ and $A=107.4 \pm 11.2$. Goodness of fit: $\mathrm{RMSE}=21.1$ and $\mathrm{ME}=0.67$

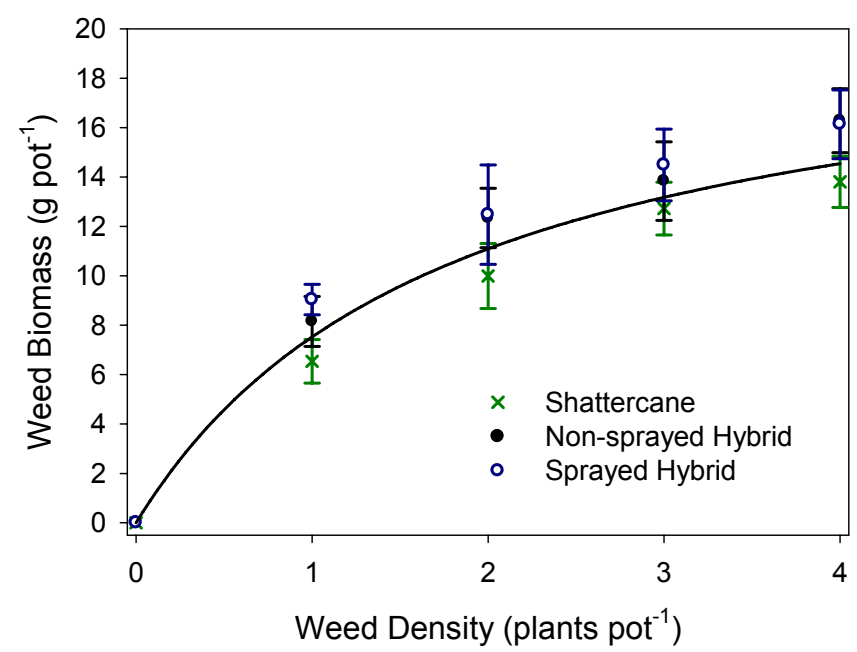

Figure 2. Relationship between aboveground weed biomass $\left(\mathrm{W}_{\mathrm{BIO}}, \mathrm{g} \mathrm{pot}^{-1}\right)$ and weed density $\left(\right.$ plants pot $\left.{ }^{-1}\right)$ at 56 days after planting. Solid line represents the best fit of equation [1] to the data and symbols represent the mean $( \pm$ standard error) for each genotype. Model coefficient estimates: $I=11.7 \pm 2.3$ and $A=21.1 \pm 2.8$. Goodness of fit:

$$
\mathrm{RMSE}=3.8 \text { and } \mathrm{ME}=0.65
$$

\subsection{Weed Biomass Production}

Shattercane and hybrid produced similar amounts of total aboveground biomass within each density, and herbicide exposure did not decrease hybrid biomass production as initially expected (Figure 2). Brenly-Bultemeier, Stachler, and Harrison (2002) reported no reduction in shoot biomass when a suspected ALS-resistant shattercane population from Ohio was sprayed with nicosulfuron at $26 \mathrm{~g} \mathrm{ha}^{-1}$. However, at this same rate, the susceptible shattercane population showed more than $90 \%$ reduction in shoot biomass compared to the untreated control. Sahoo et al. (2010) found that shattercane X sorghum F1 hybrids grew taller and produced more biomass than either parent at the end of their lifecycles. However, F1 hybrids exceeded shattercane height only at $217 \mathrm{DAP}$, but prior to that, the growth trend for both genotypes was very similar. In 
this study, shattercane and hybrid biomass were not different across densities at harvest time (Figure 2), providing support to the previous conclusion that both genotypes competed similarly against grain sorghum.

\subsection{Final Considerations}

Shattercane control is not the main objective of the Inzen Z technology, since ALS-resistant shattercane biotypes have been reported in many potential grain sorghum production areas (Brenly-Bultemeier et al., 2002; Heap, 2013; Lee, Martin, Roeth, Johnson, \& Lee, 1999). Instead, the goal of this technology is to enable farmers to manage other hard-to-control annual grasses (e.g., barnyardgrass (Echinocloa crus-galli (L.) Beauv.) and foxtails (Setaria spp.)). In a study by Hennigh et al. (2010), the mixture of nicosulfuron + rimsulfuron was very effective at controlling grasses in ALS-tolerant grain sorghum. This technology has the potential to control shattercane biotypes that have not evolved ALS-resistance; however, the current level of ALS resistance is unknown and further research needs to be conducted to address this issue. ALS-resistant shattercane biotypes could also increase after deployment of this technology due to gene flow from ALS-tolerant grain sorghum to shattercane. Therefore, this weedy relative of sorghum must be managed by alternative methods before and during adoption of ALS-tolerant grain sorghum to avoid selecting resistant genotypes.

For this research, we simulated a scenario where ALS-tolerant grain sorghum would cross with ALS-susceptible shattercane biotype and hybrids would be produced. Previous research showed that F1 hybrids will inherit the ALS-tolerance trait if hybridization between crop and wild relative occurs (Werle et al. 2013). Results of this research indicate that the F1 hybrids will compete against sorghum similarly to shattercane during early season and an ALS herbicide application at the expected recommended rate will not reduce the competitive ability of this genotype. Therefore, if hybridization occurs, the F1 hybrids must be controlled by alternative methods to avoid crop yield loss and gene introgression in weedy populations.

\section{References}

Brenly-Bultemeier, T. L., Stachler, J., \& Harrison, S. K. (2002). Confirmation of Shattercane (Sorghum bicolor) Resistance to ALS-Inhibiting Herbicides in Ohio. Plant Health Progress, Plant Management Network, St. Paul, Minnesota. http//dx.doi.org/10.1094/PHP-2002-1021-01-RS.

Cousens, R. (1985). A simple model relating yield loss to weed density. Ann. Appl. Biol., 107, 239-252. http//dx.doi.org/10.1111/j.1744-7348.1985.tb01567.x

Cousens, R. D. (1996). Comparative growth of wheat, barley, and annual ryegrass (Lolium rigidum) in monoculture and mixture. Aust. J. Agr. Res., 47, 449-464. http//dx.doi.org/10.1071/AR9960449

Defelice, M. S. (2006). Shattercane, Sorghum bicolor (L.) Moench ssp. drummondii (Nees ex Steud.) de Wet ex Davidse-black sheep of the family. Weed Technol., 20, 1076-1083. http//dx.doi.org/10.1614/WT-06-051.1

Guneyli, E., Burnside, O. C., \& Nordquist, P. T. (1969). Influence of seedling characteristics on weed competitive ability of sorghum hybrids and inbred lines. Crop Sci., 9, 713-716. http//dx.doi.org/10.2135/cropsci1969.0011183X000900060011x

Hans, S. R., \& Johnson, W. G. (2002). Influence of shattercane (Sorghum bicolor (L.) Moench.) interference on corn (Zea mays L.) yield and nitrogen accumulation. Weed Technol., 16, 787-791. http//dx.doi.org/10.1614/0890-037X(2002)016[0787:IOSSBL]2.0.CO;2

Heap, I. M. (2013). The international survey of herbicide resistant weeds. Retrieved from http://www.weedsmart.com

Hennigh, D. S., Al-Khatib, K., \& Tuinstra, M. R. (2010). Postemergence weed control in acetolactate synthase-resistant grain sorghum. Weed Technol., 24, 219-225. http://dx.doi.org/10.1614/WT-D-09-00014.1

Kegode, G. O., \& Pearce, R. B. (1998). Influence of environment during maternal plant-growth on dormancy of shattercane (Sorghum bicolor) and giant foxtail (Setaria faberi) seed. Weed Sci., 46, 322-329.

Lee, C. D., Martin, A. R., Roeth, F. W., Johnson, B. E., \& Lee, D. J. (1999). Comparison of ALS inhibitor resistance and allelic interactions in shattercane accessions. Weed Sci., 47, 275-281.

Lindquist, J. L., Mortensen, D. A., Clay, S. A., Schmenk, R., Kells, J. J., Howatt, K., \& Westra, P. (1996). Stability of corn (Zea mays)- velvetleaf (Abutilon theophrasti) interference relationships. Weed Sci., 44, 309-313.

Lindquist, J. L., Mortensen, D. A., Westra, P., Lambert, W. J., Bauman, T. T., Fausey, J. C., ... Forcella, F. (1999). Stability of corn (Zea mays)- foxtail (Setaria spp.) interference relationships. Weed Sci., 47, 195-200.

Lust, T., Barnaby Jr, G. A., O’Brien, D., \& Waller, M. (2000). Marketing. In C. W. Smith, \& R. A. Frederiksen (Eds.), Sorghum: origin, history, technology and production (pp. 591- 646). New York: John Wiley \& Sons. 
Mayer, D. G., \& Butler, D. G. (1993). Statistical validation. Ecol. Model., 68, 21-32.

Moolani, M. K., Knake, E. L., \& Slife, F. W. (1964). Competition of smooth pigweed with corn and soybeans. Weeds, 12, 126-128. http://dx.doi.org/10.2307/4040612

Motulsky, H., \& Christopoulos, A. (2003). Fitting models to biological data using linear and nonlinear regression: a practical guide to curve fitting. San Diego, CA: GraphPad Software Inc. www.graphpad.com.

Paterson, A. H. (2008). Genomics of sorghum. Int. J. of Plant Genomics, 2008, 362451. http://dx.doi.org/10.1155/2008/362451

Ritz, C., \& Streibig, J. C. (2008). Nonlinear Regression with R. New York: Springer.

Roman, E. S., Murphy, S. D., \& Swanton, C. J. (2000). Simulation of Chenopodium album seedling emergence. Weed Sci., 48, 217-224. http://dx.doi.org/10.1614/0043-1745(2000)048[0217:SOCASE]2.0.CO;2

Sahoo, L., Schmidt, J. J., Pedersen, J. F., Lee, D. J., \& Lindquist, J. L. (2010). Growth and fitness components of wild $\mathrm{x}$ cultivated Sorghum bicolor (Poaceae) hybrids in Nebraska. Am. J. Bot., 97, 1610-1617. http://dx.doi.org/10.3732/ajb.0900170

Schmidt, J. J., Pederson, J. F., Bernards, M. L., \& Lindquist, J. L. (2013). Rate of shattercane X sorghum hybridization in situ. Crop Sci., 53, 1677-1685. http://dx.doi.org/10.2135/cropsci2012.09.0536

Swanton, C., Nkoa, R., \& Blackshaw, R. E. (2013). Research methods in weed science: experimental methods for crop-weed competition studies. Weed Sci. (In press).

Tuinstra, M. R., \& Al-Khatib, K. (2008). Acetolactate synthase herbicide resistant sorghum. U.S patent application 20080216187. Alexandria, VA : U.S. patent and trademark office.

Vesecky, J. F., Feltner, K. C., \& Vanderlip, R. L. (1973). Wild cane and forage sorghum competition in grain sorghum. Weed Sci., 21, 28-32.

Werle, R., Bernards, M. L., Sattler, S. E., \& Lindquist, J. L. (2013). Susceptibility of Shattercane X ALS-Resistant Sorghum Hybrids and their Parents to Rimsulfuron and Nicosulfuron. Abstract 331 in Proceedings of the 53rd Annual Weed Science Society of America Meeting. Baltimore, MD: Weed Science Society of America.

Williams II, M. M., \& Boydston, R. A. (2006). Volunteer potato interference in carrot. Weed Sci., 54, 94-99. http://dx.doi.org/10.1614/0890-037X(2002)016[0620:VPSTCW]2.0.CO;2

Zimdahl, R. L. (2007). Fundamentals of Weed Science (3rd ed.). San Diego, CA: Academic Press.

\section{Copyrights}

Copyright for this article is retained by the author(s), with first publication rights granted to the journal.

This is an open-access article distributed under the terms and conditions of the Creative Commons Attribution license (http://creativecommons.org/licenses/by/3.0/). 